\title{
Alkaline Phosphatase, Placental Type
}

National Cancer Institute

\section{Source}

National Cancer Institute. Alkaline Phosphatase, Placental Type. NCI Thesaurus. Code C107554.

Alkaline phosphatase, placental type ( $535 \mathrm{aa}, \sim 58 \mathrm{kDa}$ ) is encoded by the human ALPP gene. This protein plays a role in phosphate metabolism. 